Gelanggang Olahraga: Jurnal Pendidikan Jasmani dan Olahraga

Volume 1, Nomor 2, Januari-Juni 2018

e-ISSN : 2597-6567

p-ISSN : 2614-607X

DOI : https://doi.org/10.31539/jpjo.v1i2.136

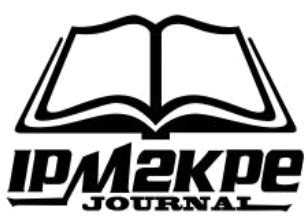

\title{
PELAKSANAAN PROSES BELAJAR MENGAJAR PENDIDIKAN JASMANI OLAHRAG DAN KESEHATAN \\ PADA SEKOLAH DASAR
}

\author{
Muhamamad Supriyadi \\ Dosen STKIP-PGRI Lubuklinggau \\ Muhammadsupriyadi.030190@gmail.com
}

\begin{abstract}
ABSTRAK
Tujuan penelitian ini adalah untuk mengetahui bagaimana metode pengajaran, dan sarana prasarana Pendidikan Jasmani Olahraga dan Kesehatan di Sekolah Dasar Negeri 23 V Koto Timur Kabupaten Padang Pariaman.Metode penelitianya deskriptif hasil penelitian terlihat bahwa pelaksanaan proses belajar mengajar praktek pendidikan jasmani olahraga dan kesehatan di Sekolah Dasar Negeri $23 \mathrm{~V}$ Koto Timur Kabupaten Padang Pariaman adalah sebagai berikut: dari segi metode pengajaran dengan indikator demonstrasi memiliki jumlah rata-rata persentase jawaban 80 kali $(50 \%)$ dengan kriteria sedang dan indikator ceramah memiliki jumlah rata-rata persentase jawaban 136 kali (60.71\%).Untuk sarana dan prasarana dengan indikator peralatan olahraga memiliki rata-rata persentase jawaban siswa 130 kali (50.78\%) dengan kriteria sedang. Dari hasil diatas dapat disimpulkan bahwa pelaksanaan proses belajar mengajar praktek pendidikan jasmani olahraga dan kesehatan di Sekolah Dasar Negeri 23 V Koto Timur Kabupaten Padang Pariaman berada dalam kategori " sedang".
\end{abstract}

Kata Kunci : Proses Belajar Mengajar, Pendidikan Jasmani Olahraga dan Kesehatan.

\begin{abstract}
The purpose of this research is to know how the method of teaching, and infrastructure facilities of Physical Education of Sport and Health at State Elementary School 23 V East Koto Padang Pariaman Regency. His research method descriptive research finds that the implementation of teaching and learning process of physical education practice in health and elementary school Country 23 V Koto Timur Padang Pariaman District is as follows: in terms of teaching methods with demonstration indicators have the average number of answers 80 times (50\%) with medium criteria and lecture indicator has the average number of answers 136 times (60.71\% ). For facilities and infrastructure with sports equipment indicator have average percentage of student answer 130 times (50.78\%) with medium criterion. From the above results can be concluded that the implementation of teaching and learning process physical exercise and health education in Public Elementary School 23 V East Koto Padang Pariaman Regencyisinthecategoryof"being".
\end{abstract}

Keywords: Teaching and Learning Process, Physical Education Sport and Health 


\section{PENDAHULUAN}

Depdiknas (2006) mengemukakan bahwa: "pendidikan jasmani, olahraga dan kesehatan merupakan bagian integral dari pendidikan secara keseluruhan, bertujuan untuk mengembangkan aspek kebugaran jasmani, keterampilan gerak, keterampilan berfikir kritis, keterampilan sosial, penalaran, stabilitas emosional, tindakan moral, aspek pola hidup sehat dan pengenalan lingkungan bersih melalui aktifitas jasmani, olahraga dan kesehatan terpilih yang direncanakan secara sistematis dalam rangka mencapai tujuan pendidikan nasional”.

Berdasarkan penjelasan di atas penjasorkes merupakan bagian dari keseluruhan mata pelajaran yang diajarkan disekolah dan tidak dapat dipisahkan dengan pendidikan lainnya, bahkan merupakan bagian pendidikan yang sangat penting dalam mendukung proses pendidikan yang lainnya.

Selanjutnya penjelasan di atas jelas bahwa mata pelajaran Penjasorkes merupakan salah satu mata pelajaran yang ada di SD yang harus mendapatkan perhatian yang cukup serius karena di dalam materi Penjasorkes tersebut terdapat nilai - nilai yang antara lain kreatifitas, disiplin, kerjasama dan melatih diri untuk hidup sehat dalam perkembangan aspek kognitif, afektif, mental, moral dan emosional, dalam pengertian yang luas dan karena itu Penjasorkes merupakan mata pelajaran yang juga ikut mempengaruhi perkembangan kepribadian siswa dan ikut serta berkonstribusi dalam mencapai tujuan pendidikan nasional. Dengan demikian pendidikan harus dilaksanakan dengan tertib dan bertanggung jawab.

Namun realitanya pelaksanaan praktek Penjasorkes di Sekolah Dasar Negeri 23 V Koto Timur Kabupaten Padang Pariaman yang dilaksanakan masih kurang berjalan dengan baik dan lancar. Informasi yang didapat dari kepala sekolah dan guru penjas adalah guru penjasorkes belum menggunakan metode pengajaran yang tepat dan sarana prasarana yang belum mencukupi sehingga dapat menjadi hambatan dalam belajar praktek pendidikan jasmani.Untuk meningkatkan proses pembelajaran maka peneliti perlu melakukan pengembanganAgar proses pembelajaran praktek penjasorkes yang dilaksanakan dapat tercapai, maka adanya suatu cara yang disusun secara sistematis, cara ini yang dimaksud adalah metode. Metode dalam ilmu pendidikan jasmani adalah "cara-cara mengajar khusus yang digunakan dalam mengolah pengetahuan, prinsip - prinsip, norma - norma, peraturanperaturan yang berlaku dalam pendidikan olahraga atau semua yang penting dalam proses belajar motorik untuk tercapainya keefektifan dalam belajar"

Hal ini dapat penulis sampaikan bahwa siswa tidak dapat memperhatikan instruksi-instruksi gerakan yang akan dilakukan disebabkan dari faktor sosial budaya siswa, seperti; mendang bola.Dalam hal ini siswa banyak tidak mampu karena kurangnya melakukan latihan,untuk melakukan teknik gerakan yang baik, bola yang dijadi sarana bola yang terbuat dari kerta dalam artian terjadi modifikasi sarana dan prasarana yang mengakibat siswa menjadi tidak bosan

Sehingga dalam proses pembelajaran hampir keseluruhan materi di lakukan dalam bentuk modifikasi sarana dan prasarana dan hal dilakukan pada dalam proses mencapai tujuan pendidikan jasmani agar sesuai dengan tujuan pendidikan nasional.

Hambatan atau kendala yang dihadapi dalam mengajar praktek penjasorkes di Sekolah Dasar Negeri 23 V Koto Timur Kabupaten Padang Pariaman pada siswa kelas III sampai kelas VI yang disampai diatas dapat disimpulkan diantaranya; metode pengajaran yang diberikan oleh guru kurang 
tepat, sarana dan prasarana yang tidak mencukupi, kurang bersemangat, malas, lokasi yang jauh dan aktifitas sekolah yang padat yang membuat siswa sering lelah serta malas untuk berkeringat ini merupakan anggapan yang disampaikan.

Berdasarkan gejala diatas maka masalah kurang terlaksananya pembelajaran pendidikan jasmani olahraga dan kesehatan juga dipengaruhi oleh metode pembelajaran yang diberikan dalam proses pembelajaran penjas. Dalam proses pembelajaran pada saat ini sebuah metode pembelajaran tidak cukup kita dengan memberika instruksi dan paparan saja kepada siswa hal lain juga harus mampu kita lakukan seperti demonstrasi dengan modifikasi sarana.Dan oleh permasalahan di atas penulis tertarik dan merasa penting untuk melakukan penelitian. Penelitian yang dimaksud adalah tentang bagaimana "Pelaksanaan Studi Proses Belajar Mengajar Pendidikan Jasmani Olahraga Dan Kesehatan di Sekolah Dasar Negeri 23 V Koto Timur Kabupaten Padang Pariaman”.

\section{KAJIAN TEORI}

Penjasorkes pada dasarnya merupakan bagian integrasi dari sistem pendidikan secara keseluruhan yang bertujuan untuk mengembangkan aspekkesegaran dan kebugaran jasmani pada setiap individu sehingga individu memiliki keterampilan berfikir kritis, stabilitas emosional, keterampilan sosial, penalaran dan tindakan moral melalui aktivitas jasmani dan olahraga.

Sistem Keolahragaan tahun 2005 menjelaskan bahwa, pembinaan dan pengembangan olahraga pendidikan pasal 25 ayat 4 adalah: "pembinaan dan pengembangan olahraga pendidikan dilaksanakan dengan memperhatikan potensi, kemampuan, minat, dan bakat peserta didik secara menyeluruh, baik melalui kegiatan intrakurikuler maupun ekstrakurikuler".

Berdasarkan penjelasan di atas dapat dikatakan bahwa penjasorkes adalah dapat meningkatkan potensi yang ada dalam diri anak didik, dapat meningkatkan minat dalam mengikuti pelajaran pendidikan jasmani serta dapat menyalurkan bakat yang ada pada diri anak didik melalui kegiatan yang bermanfaat. Dari proses pembangunan, guru penjasorkes diharapkan dapat mengajar berbagai keterampilan gerak dasar, teknik dan strategi permainan dan olahraga. Internalisai nilai-nilai (sportifitas, jujur, kerjasama dan lain-lain) serta pembiasaan pola hidup sehat yang pelaksanaannya bukan melalui pengajaran konvensional didalam kelas yang bersifat teoritis, tetapi melibatkan aspek fisik, mental, intelektual, emosional dan sosial peserta didik. Pelaksanaan pembelajaran penjasorkes harus disesuaikan dengan tujuan yang akan dicapai oleh pembelajaran pendidikan jasmani itu sendiri dan hal ini sangat didukung oleh metode yang akan dilaksanakan oleh guru. Melalui metode yang akan di terapkan oleh guru penjasorkes diharapkan mampu memberikan penjelasan yang tepat mengenai materi yang akan diajarkan kepada anak didik, baik secara verbal maupun non-verbal.

Metode yang biasa digunakan guru dalam menyampaikan materi penjasorkes adalah metode deduktif atau metode perintah, metode tugas, demonstrasi dan pemberian penjelasan. Guru memberikan contoh gerakan yang akan diajarkan dan siswa berusaha mengembangkan dan melaksanakan bentuk gerak yang telah diajarkan, dimana siswa turut aktif berpartisipasi dalam kegiatan belajar, sehingga pembelajaran pendidikan jasmani menghasilkan keterampilan gerak bagi siswa. 
Dalam pembelajaran pendidikan jasmani aspek psikomotor merupakan tujuan utama yang akan dicapai tanpa mengabaikan aspek-aspek pendidikan yang lain seperti aspek kognitif, afektif dan sosial.Pelaksanaan pembelajaran pendidikan jasmani umumnya mencakup 3 hal yaitu:

\section{Pretest}

Pretest adalah tes yang diberikan oleh guru sebelum pengajaran dimulai, dan bertujuan untuk mengetahui sampai dimana pengetahuan siswa terhadap bahan pelajaran (pengetahuan atau keterampilan) yang akan diajarkan.

Fungsi pretest adalah:

1. Menyiapkan peserta didik dalam proses belajar

2. Mengetahui tingkat kemajuan peserta didik sesuai dengan proses pembelajaran yang dilaksanakan

3. Mengetahui kemampuan awal yang telah dimiliki peserta didik mengenai bahan pelajaran yang akan dijadikan materi didalam proses pembelajaran.

4. Mengetahui darimana seharusnya proses pembelajaran dimulai, tujuan mana yang telah dikuasai siswa dan tujuan mana yang perlu mendapatkan penekanan dan perhatian khusus.

\section{Proses}

Proses yang dimaksudkan adalah pembelajaran inti dan pelaksanakaan proses pembelajaran, yakni bagaimana tujuan -tujuan pengajaran direalisasikan. Proses pembelajaran dikatakan efektif apabila seluruh siswa terlibat secara aktif di dalam pelaksanaan pembelajaran penjasorkes.

\section{Pos-test}

Pos-test adalah tes yang diberikan pada setiap akhir program satuan pembelajaran. Tujuan pos-test adalah untuk mengetahui sampai dimana pencapaian siswa terhadap bahan pengajaran (pengetahuan dan keterampilan) setelah mengalami suatu kegiatan belajar.

Fungsi pos-test adalah:

1. Mengetahui tingkat penguasaan siswa terhadap kompetensi yang telah ditentukan.

2. Mengetahui kompetensi dan tujuan yang dapat dikuasai dan bila sebagian besar belum dapat menguasai maka diadakan pembelajaran kembali

3. Mengetahui siswa yang perlu mengikuti program pengayaan untuk mengetahui tingkat kesulitan yang dihadapinya.

4. Sebagai acuan perbaikan terhadap komponen-komponen proses pembelajaran yang telah dilaksanakan, baik terhadap perencanaan, pelaksanaan dan evaluasi.

Seperti telah dikatakan di atas, jika hasil pos-test dibandingkan dengan hasil pretest, maka keduanya berfungsi untuk mengukur sampai sejauh mana keefektifan pelaksanaan program pembelajaran.

\section{Metode Pengajaran}

Dalam ilmu pendidikan jasmani dapat dikatakan bahwa, metode adalah cara-cara mengajar khusus yang digunakan dalam mengolah pengetahuan , prinsip- prinsip, norma-norma, peraturan-peraturan yang berlaku dalam 
pendidikan olahraga atau semua yang penting dalam proses belajar motorik untuk tercapainya keefektifan dalam belajar.

Selanjutnya dalam pengajaran olahraga dikenal ada beberapa metode mengajar yang sering dipakai, diluar dari metode yang diatas. Metode tersebut yaitu: metode induktif dan metode deduktif. Kedua metode itu mempunyai konsep yang khas dan memiliki langkah-langkah yang konkrit dalam penggunaannya.

\section{Metode Induktif}

Menurut Djusma (1995) metode mengajar induktif menempatkan kemandirian dan self-acting pada latar depan dan menerima jalan yang berbelitbelit (memutar) pada proses belajar. Disamping itu Fetz (1975) berpendapat metode induktif sangat sesuai dengan sekolah, kerja, peserta didik lebih aktif belajar mandiri sedangkan guru cukup membimbing.

Jadi metode mengajar deduktif merupakan suatu metode mengajar dimana konsep kegiatan belajar harus melalui langkah seperti adanya tugas gerakan, berusaha mencari dan mencoba, menemukan, koreksi, kemudian berlatih dan penerapan. Keenam langkah tersebut terlebih dahulu murid harus tahu dan mengerti menggunakannya, karena memang mereka yang aktif. Ini bertujuan agar tujuan pelajaran dapat tercapai pada waktunya.

Dengan metode ini sangat terasa bagi peserta didik yaitu mereka harus aktif dan mengerti dengan langkah-langkah yang harus mereka lalui dari awal pelajaran sampai akhir. Tentu saja guru semestinya mendisain materi pelajaran demikian menarik, sehingga memancing motivasi dan kreatifitas mereka secara optimal.

\section{Metode Deduktif}

Selama ini ada kesan pada sebagian orang yang mengatakan bahwa mengajar dengan metode deduktif dianggap paling baik. Di sisi guru dianggap orang yang sudah tahu akan segala yang akan diajarkannya. Metode deduktif dalam mengajar akan memperlihatkan bahwa guru adalah sumber segalanya. Tanpa ada alternatif kompromi antara keduanya. Murid baru melakukan semua yang diinstruksikan guru. Dominasi guru pada metode ini tidak dipersoalkan dan prosedur yang dikemudikannya memberikan ruangan gerak yang tidak berarti bagi murid untuk membuat keputusan sendiri, tetapi pada sisi lain tujuan belajar yang telah ditetapkan akan tercapai ((Djusma 1995).

\section{METODE PENELITIAN}

Arikunto (1996) mendefenisikan bahwa "penelitian deskriptif" adalah "penelitian yang tidak bermaksud untuk menguji hipotesis tertentu tetapi hanya menggambarkan apa adanya tentang suatu variable gejala atau keadaan”.

Berdasarkan defenisi diatas maka diketahui bahwa penelitian ini hanya mengungkapkan atau menggambarkan suatu gejala semata yaitu "melihat bagaimana Pelaksanaan Proses Belajar Mengajar Praktek Pendidikan Jasmani di Sekolah Dasar Negeri 23 V Koto Timur Kabupaten Padang Pariaman”. 
Penelitian ini direpada bulan Desember 2011 di Sekolah Dasar Negeri 23 V Koto Timur Kabupaten Padang Pariaman. Populasi dalam penelitian ini adalah siswa Sekolah Dasar Negeri 23 V Koto Timur Kabupaten Padang Pariaman yang terdiri dari kelas I sampai kelas VI.

Berdasarkan jumlah populasi 131 orang maka ditarik sampel sebanyak 32 orang siswa dari jumlah populasi di Sekolah Dasar Negeri $23 \mathrm{~V}$ Koto Timur Kabupaten Padang Pariaman, jadi jumlah sampel pada penelitian berjumlah 32 orang siswa. Yusuf (2005) menyatakan ; "sampel adalah sebagian dari populasi yang terpilih dan mewakili populasi tersebut"

Selanjutnya untuk siswa kelas I dan kelas II tidak diikut sebagai sampel hal ini dikarenakan keterbatasan siswa dalam membaca dan mengisi angket, sedangkan untuk siswa kelas VI juga tidak dipilih sebagai sampel karena para siswa sedang mempersiapkan diri dalam menghadapi Ujian Nasional.

Jenis data dalam penelitian ini adalah bersifat primer dan sekunder, yang dimaksud data primer di dalam penelitian ini adalah data yang langsung diperoleh dari responden dengan cara menyebarkan angket/kuesioner terbuka kepada seluruh sampel, sedangkan data sekunder adalah data yang diambil secara tidak langsung dari sumbernya yaitu melalui dokumen-dokumen yang ada disekolah. Sumber data primer diperoleh langsung dari jawaban populasi di Sekolah Dasar Negeri 23 V Koto Timur Kabupaten Padang Pariaman sebagai responden yang diisi melalui penyebaran angket, selain itu data juga diperoleh langsung dari hasil wawancara pada sampel, sedangkan untuk data sekunder, diambil dari tata usaha serta kearsipan yang ada disekolah. Data pada penelitian diperoleh dengan menggunakan cara observasi, wawancara dan quesioner atau dengan penyebaran angket. Langkah-langkah yang dilakukan dalam pembuatan angket yaitu terlebih dahulu membuat kisi-kisi pertanyaan berdasarkan indikator-indikator dari variabel, kemudian barulah pertanyaan-pertanyaan tersebut disusun untuk dijadikan sebagai angket. Jenis angket yang digunakan adalah angket tertutup, dimana responden diberikan alternatif jawaban dan diminta untuk memilih jawaban yang telah tersedia. Setelah angket disebarkan dan dikumpulkan, selanjutnya dilakukan pengolahan data berdasarkan angket yang telah dikumpulkan dan telah memenuhi syarat untuk dianalisis. Teknik analisis data yang digunakan statistik deskriptif yang menggunakan tabulasi frekuensi (Sudjana 1990).

\section{HASIL PENELITIAN}

Pada bagian ini akan dilakukan analisis terhadap hasil penelitian. Sesuai dengan pertanyaan penelitian yang diajukan, sebelum dilakukan analisis terhadap data tersebut tentang "Pelaksanaan Proses Belajar Mengajar Praktek Pendidikan Jasmani Olahraga Kesehatan di Sekolah Dasar Negeri 23 V Koto Timur Kabupaten Padang Pariaman" yang ditinjau dari aspek metode pengajaran dan sarana prasarana, maka dilakukan verifikasi (seleksi) terhadap data yang diperoleh.

Tujuan dilakukan verifikasi data adalah apabila ada data yang tidak lengkap yang di isi oleh responden dalam instrumen, maka data tersebut tidak dapat diolah. Kriteria lengkapnya data yang di isi responden terhadap instrumen, apabila seluruh pertanyaan dijawab sesuai dengan instruksi yang ada dalam instrumentasi tersebut. Berdasarkan hasil verifikasi terhadap data yang diberikan, ternyata semua dapat diolah. 
Data yang terkumpul berupa skor dimana setiap item yang telah dijawab diberi bobot 1 dan 0 . skor tersebut merupakan data hasil penelitian.Dari hasil pengolahan data, dapat dideskripsikan data sebagai berikut:

1. Secara umum Pelaksanaan Proses Belajar Mengajar Praktek Pendidikan Jasmani Olahraga Kesehatan di Sekolah Dasar Negeri 23 V Koto Timur Kabupaten Padang Pariaman termasuk kedalam kriteria sedang

2. Persentase dan kriteria dalam Pelaksanaan Proses Belajar Mengajar Praktek Pendidikan Jasmani Olahraga Kesehatan di Sekolah Dasar Negeri 23 V Koto Timur Kabupaten Padang Pariaman dilihat dari masing-masing sub variabel.

Tabel 1

Persentase dan Kriteria Pelaksanaan Proses Belajar Mengajar Praktek Pendidikan Jasmani Olahraga Kesehatan

\begin{tabular}{clcc}
\hline No & \multicolumn{1}{c}{ Sub Variabel } & Persentase & Kriteria \\
\hline 1 & Metode Pengajaran & $60 \%$ & Sedang \\
2 & Sarana dan prasarana & $40 \%$ & Sedang \\
\hline
\end{tabular}

3. Persentase dan kriteria pelaksanaan proses belajar mengajar praktek pendidikan jasmani olahraga kesehatan di Sekolah Dasar Negeri 23 V Koto Timur Kabupaten Padang Pariaman dilihat dari masing-masing indikator

Tabel 2

Persentase dan Kriteria Pelaksanaan Proses Belajar Mengajar Praktek Pendidikan Jasmani, Olahraga dan Kesehatan

\begin{tabular}{llccc}
\hline No & Sub Variabel/Indikator & $\mathbf{F}_{\text {absolut }}$ & Persentase & Kriteria \\
\hline 1 & Metode Pengajaran & & & \\
& $\begin{array}{l}\text { : Demonstrasi } \\
\text { : Ceramah }\end{array}$ & 136 & 50,00 & Sedang \\
2 & $\begin{array}{l}\text { Sarana dan prasarana } \\
\text { • Peralatan Olahraga }\end{array}$ & 130 & 50,71 & Tinggi \\
& & & & Sedang \\
\hline
\end{tabular}

\section{PEMBAHASAN}

Tingkat keberhasilan suatu proses pembelajaran juga ditentukan oleh pengertian tentang konsep-konsep/istilah yang digunakan dan mendasari proses pembelajaran tersebut. Didalam proses pembelajaran kita akan selalu menggunakan istilah metode yang pengertian ini akan sangat berbeda jika metode tersebut dipandang dari bidang lain. Secara umum pengertian metode adalah caracara (segala tindakan/aktifitas) yang terencana untuk mencapai tujuan tertentu dalam bidang ilmu pengetahuan dan praktek, sedangkan pengertian dalam ilmu pendidikan jasmani/olahraga metode adalah cara-cara mengajar khusus yang digunakan dalam mengolah pengetahuan, prinsip-prinsip, norma-norma, peraturan-peraturan yang berlaku dalam pendidikan olahraga atau semua yang penting dalam proses belajar motorik untuk tercapainya keefektifan dalam belajar. Demonstrasi merupakan suatu cara mengajar/teknik mengajar dengan mengkombinasikan lisan dengan suatu perbuatan serta dipergunakan suatu alat, 
sehingga akan lebih menambah penjelasan lisan, lebih menarik perhatian anak dan sebagainya. Nilai metode demonstrasi

1. Memberi gambaran dan pengertian yang lebih jelas dari pada hanya dengan lisan.

2. Untuk menunjukkan lebih jelas langkah-langkah suatu proses atau suatu keterampilan.

3. Untuk lebih memudahkan, lebih efesien.

4. Memberi kesempatan kepada anak untuk belajar mengamati sesuatu dengan cermat.

5. Setelah demonstrasi akan memberikan kesempatan kepada anak untuk diskusi yang akan lebih memperbaiki dan mempertajam pengertian.

Melaksanakan demonstrasi

1. Ciptakan suasana yang baik. Jelaskan tujuan demonstrasi dan bangkitkan minat siswa.

2. Usahakan agar demonstrasi itu sederhana dan hanya mengenai pokokpokoknya saja yang mudah difahami anak.

3. Jangan menyimpang dari pokok.

4. Selalu perhatikan, apakah demontrasi itu cukup dipahami anak.

5. Jangan melakukan demonstrasi itu terburu buru.

6. Jangan demonstrasi itu diperpanjang, sehingga membosankan.

7. Sambil melakukan demonstrasi pada saat-saat tertentu, kita membuat rangkuman apa yang telah dipertunjukkan.

Selain indikator diatas, ada indikator lain sebagai penyebab hambatan belajar siswa dalam pembelajaran pendidikan jasmani, olahraga dan kesehatan yaitu indikator ceramah dengan persentase jawaban 85 kali $(60.71 \%)$ dengan kriteria sedanga siswa dapat belajar dengan baik, maka metode mengajar harus diusahakan yang tepat, efesien dan efektif mungkin. Sebaliknya, jika metode mengajar yang digunakan guru salah maka siswa tidak akan menyenangi pelajaran tersebut sehingga akan timbul hambatan dalam belajar bagi siswa.seperti dapat dilihat pada grafik dibawah ini.

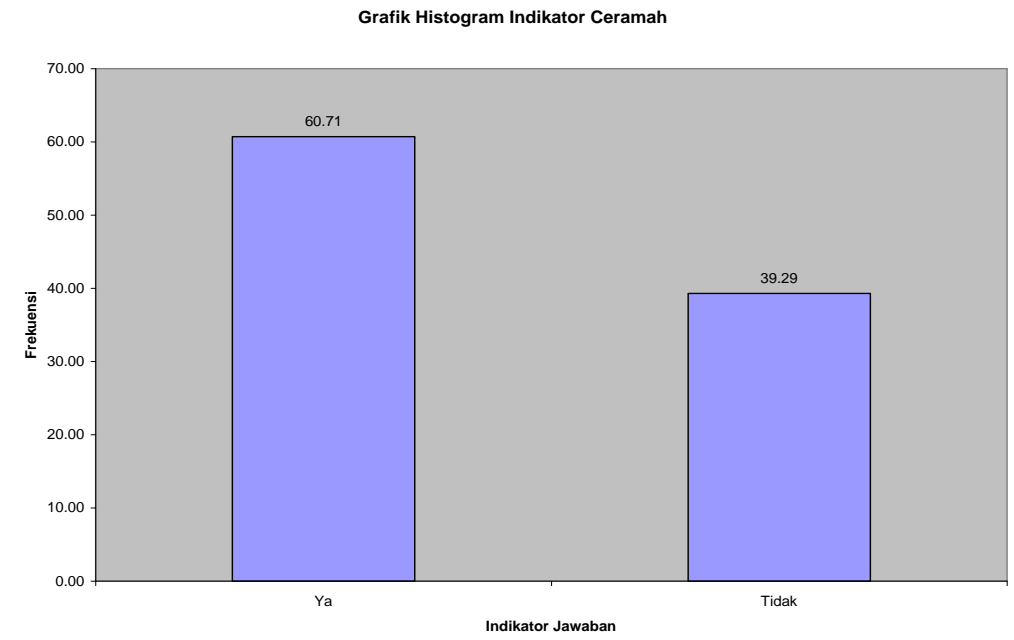

Grafik 1. Histogram Sub Variabel Metode Ceramah 
Mengajar bertujuan menyampaikan pengetahuan pada siswa. Metode ceramah juga disebut metode memberitahukan atau metode kuliah. Sebenarnya bukan hanya memberitahukan, yakni menyampaikan sejumlah keterangan atau fakta - fakta, tetapi dengan ceramah dimaksud juga menjelaskan/menguraikan kepada siswa mengenai suatu masalah, topik atau pertanyaan.

Tujuan metode ini adalah pengisian/penumpukan pengetahuan kepada murid, yang dianggap masih kosong dan pasif. Pengajaran ini berpusat pada guru. Metode ceramah tidak memberikan kesempatan untuk berbuat dan berfikir, untuk memecahkan masalah, metode ini tidak cukup untuk memberi kesempatan kepada anak-anak mengembangkan kecakapan untuk mengeluarkan pendapat sendiri. Di samping itu agar tujuan tercapai dengan baik, maka sarana dan prasarana yang digunakan harus sesuai dan tercukupi untuk proses pembelajaran.

\section{SIMPULAN}

Dari hasil penelitian yang dilakukan dapat disimpulkan bahwa 1) Metode Pengajaran memberikan cara yang cukup baik terhadap menyelesaiakan hambatan belajar siswa dan memiliki kriteria sedang sebagai hambatan belajar belajar Pendidikan Jasmani Olahraga dan Kesehatan, 2) Sarana dan Prasarana yang kurang mencukupi menyebabkan hambatan belajar bagi siswa untuk mengikuti pelaksanaan praktek proses belajar mengajar yang dilaksanakan diluar jam sekolah.Adapun saran - saran yang dapat penulis kemukakan sebagai berikut: 1) diharapkan kepada guru mata pelajaran untuk lebih meningkatkan metode pengajaran yang menarik sehingga siswa lebih tertarik untuk mengikuti proses belajar mengajar Praktek Pendidikan Jasmani, Olahraga dan Kesehatan, 2) diharapkan kepada pihak sekolah dan guru Pendidikan Jasmani, Olahraga dan Kesehatan untuk melengkapi segala bentuk sarana atau peralatan olahraga demi kelancaran proses belajar mengajar. 


\section{DAFTAR PUSTAKA}

Arikunto. (1996). Penelitian Deskriptif.Jakarta. Depdikbub.

Depdiknas. (2006). Metode Penelitian Administrasi. Bandung: Albabeta Bandung. . (2003). Undang-Undang Republik Indonesia Nomor 20 Tahun2003.

Tentang Sistem PendidikanNasional. Jakarta: Depdiknas.

(2005). Kurikulum 2004 Standar Kompetensi Mata Pelajaran Pendidikan Jasmani. Jakarta: Depdiknas.

(2006). Kurikulum Tingkat Satuan Pembelajaran. Jakarta: Depdiknas.

Djusma. (1995). Pengantar Didaktik Olahraga. FPOK IKIP Padang.

Fets. F. (1975). Allegement Methode Der Leibesubungen. Frankfurt.

Sudjana. (1990). Metode Penelitian Kualitatif. Jakarta: Pustaka Setia

Yusuf. (2005). Metode Penelitian Administrasi. Bandung: Albabeta Bandung 